\title{
Employees' Engagement in the Context of the Reliability of Information Systems in the Organization
}

\author{
Katarzyna Tworek*, PhD \\ Wroctaw University of Science and Technology, Faculty of Computer Science and Management, Poland \\ *Corresponding Author: Katarzyna Tworek, Wroctaw University of Science and Technology, Faculty of \\ Computer Science and Management, Poland
}

\begin{abstract}
The article presents an analysis of the literature indicating the potential relation between the level of employees' engagement and the level of information systems (IS) reliability in the organization. Next, empirical studies are presented to verify this relation as the first step of the analysis verifying IS as a potential factor that could shape the level of employees' engagement in the organization. The article contains a description of empirical research conducted in 2018 among 557 organizations operating in Poland and the results show that there is a statistically significant relation between the level of employees' engagement and the level of IS reliability in the organization. The strongest relation is identified between the level of employees' engagement and the level of IS usage reliability perceived by employees, which is consistent with the analysis of the literature.
\end{abstract}

Keywords: Information Systems, IS Reliability, Employees’ Engagement, Organization

\section{WPROWADZENIE}

In recent years, the literature indicates the growing importance of employees' commitment in the organization as a factor affecting the organization's ability to build competitive advantage and stay on the market (Kompaso and Sridevi, 2010, Clifton, 2008). Employees' commitment is a subject that appeared in the literature in the 1990s and was initially mixed with the English-language concepts: "high commitment", "high involvement", "high performance" (Wood and DeMezenes, 1998).Over time the management method was formed and is now referred to as "High Commitment Management (HCM)" (Grobelna, 2014; Juchnowicz, 2010).

However, publications on the Polish business context are rare and the majority of the few empirical studies concerning not only the management method itself, but the level of employees' commitment in Poland, were carried out almost 10 years ago, e.g. by Juchnowicz (2010). Considering the fact that this subject is relatively new not only in Poland, empirical research indicating what factors may potentially affect the level of employees' commitment are also quite rare (Kompaso and Sridevi, 2010, Clifton, 2008, Macey and Schneider, 2008) and focused around the strategy of shaping the level of commitment and not the factors that influence it. In the context of the growing importance of employees' commitment in the organization and the need to indicate mechanisms for shaping the factors that build the level of this commitment, this is a clear research gap.

Considering current market conditions, almost every organization uses information systems (IS) as a support for implemented management methods (Crowston, 2000, Tworek, 2016). Therefore, it is not unreasonable to state that the SI used in the organization and their usefulness perceived by employees (forced to use them on a day-to-day basis) can potentially affect the level of commitment of these employees. This article will consider the relation between the use of IS in the organization and the level of employees' commitment. The model of IS reliability in the organization, developed and verified by Tworek (2019), was used to assess the perceived usefulness of IS. The purpose of this article is to verify the existence of a relation between the reliability of IS in the organization and the level of employees' commitment. This verification will be based on empirical studies conducted on a sample of 557 organizations operating in Poland and declaring the use of the High Commitment Management (HCM) method. 


\section{THEORETICAL BACKGROUND}

\subsection{Employees' Commitment}

Robinson et al. (2014) indicate that employees' commitment is shaped by the formation of their sense of being appreciated, which is influenced by: development and further training opportunities, rewards and bonuses related to their effectiveness, bilateral communication with superiors, placement conditions and health. Typically, three types of employees' commitment are indicated for systematisation (Jha and Kumar, 2016). The first is social commitment. It is a type of commitment that manifests itself in the fact that the employee communicates with other members of the team and organization. The second is intellectual commitment. This type of commitment manifests itself in the fact that the employee uses his / hers intellect not only to perform tasks, but also to continuously improve the efficiency of performing these tasks. The third of them is emotional commitment. It is a type of commitment manifested in the fact that the employee is emotionally involved to fulfill the goals of the organization.

Mone i London (2009) and Mone et al. (2018) developed a methodology for assessing the level of employees'commitment, taking into account all the types indicated by Jah and Kumar (2016) and indicating 8 typical premises, which fulfillment determines this level:

- employees are motivated to improve their productivity and find better ways to do their job,

- communication on the part of the organization's management helps employees to understand the strategies, missions and goals of the organization,

- employees feel that they have enough resources to do their job effectively,

- employees feel that the management of the organization thinks about their good,

- employees are satisfied with the possibilities of promotions and personal development,

- employees recognize that not only payment, but also additional benefits and work atmosphere are pros of employment,

- employees have confidence in the management of the organization,

- employees feel that they receive enough feedback from their superiors to improve their efficiency on this basis.

However, this is not the only commonly accepted methodology for assessing the level of employees' commitment. Marrelli (2011) proposes 3 sets of premises, which in his opinion more clearly determine whether the employees of the organization can be considered as highly commited (equivalent to "high commitment"), moderately commited or poorly commited. Highly commited employees were characterized by Marrelli (2011) as those who:

- they do what they can to do their work effectively every day,

- they put the interest of the organization above their own,

- they are innovative and constantly come up with new ideas,

- they are willing to voluntarily contribute to the organization's success,

- they try to make the working environment created by them pleasant and respectful.

However, it seems that all the methods described above for analyzing and assessing the level of employees' commitment define a consistent set of premises defining the level of commitment and are not mutually exclusive, but rather consistently build a unified concept.

\subsection{IS Reliability}

In the context of the employees' commitment level understood in this way, it seems particularly important to consider the IS in the organization in relation to the way employees perceive it. In addition, due to the fact that the need to use IS in an organization seems unchallenged for many years, it is necessary to analyze and evaluate their actual use in the organization. The $3 \mathrm{R}$ concept (reliability, resilience and robustness) appeared in the literature a few years ago (Little, 2003) and emphasizes that 
the key factors influencing the ability to use the IS is their proper functioning in the organization and awareness and acceptance of their usefulness among employees. Therefore, IS will be considered in the context of the IS reliability evaluation methodology in the organization developed by Tworek (2019) and taking into account the above-mentioned postulates.

The IS reliability in the organization is understood according to Zahedi (1987) as a measurable IS property, useful for their control and management, identifying their quality level and indicating potential problems. It is directly related to the performance of IS components, especially those critical to proper operation. The model of IS reliability in the organization is based on factors related to three different IS assessment methodologies in the organization. The first one is the success model of DeLone and McLean (2003), the second is the model of 4 IS failures by Lyytinen (1987) and the third is the technology acceptance model TAM (Davis, 1985). They build 4 elements of the IS reliability model in the organization (shown in Figure 1): reliability of the system (software and hardware), its usage, information contained therein and support services.

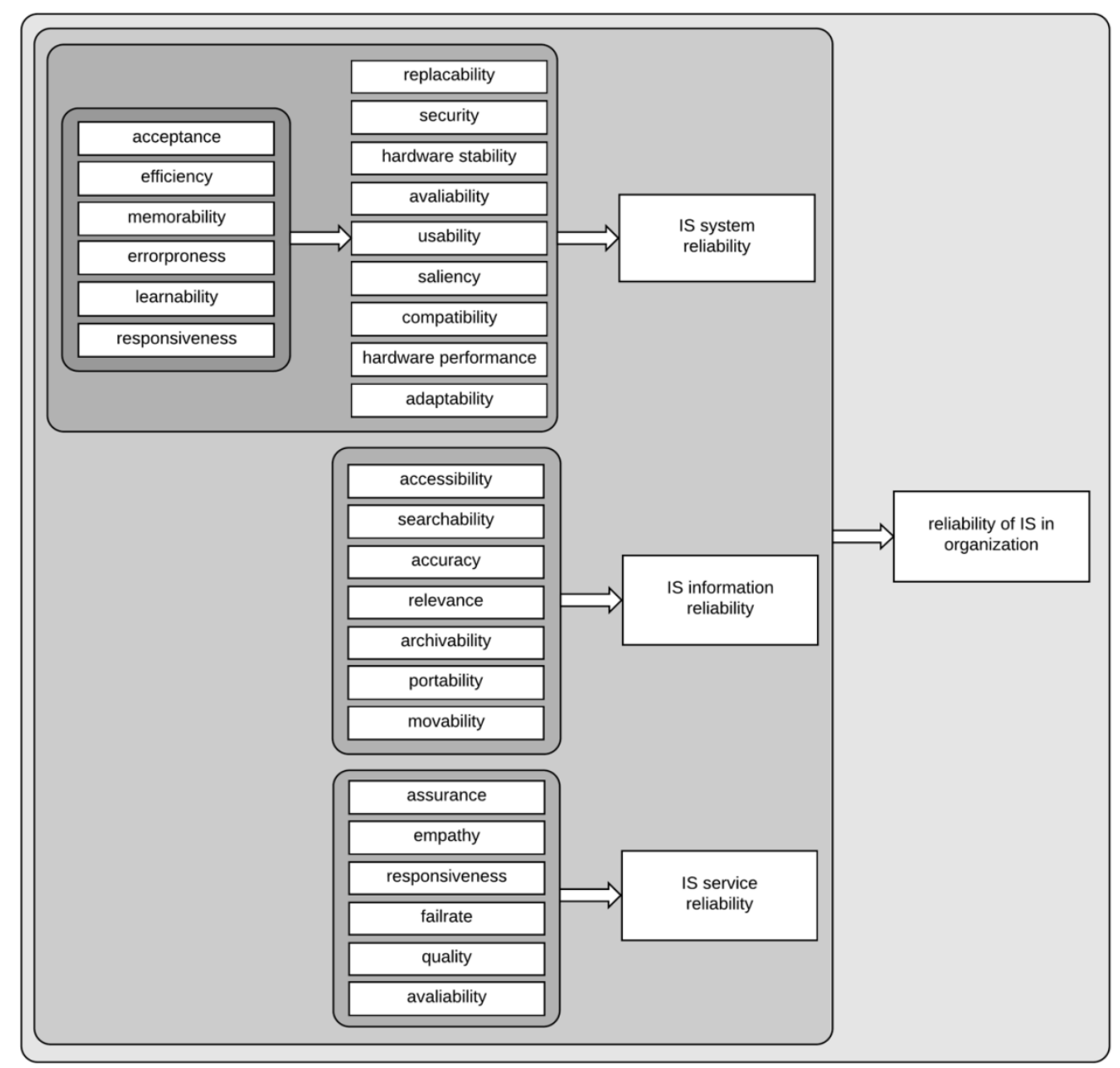

Fig1. Reliability of IS in organization.

Source: (Tworek, 2018)

The reliability model of IS in the organization and a set of factors that build each of the 4 elements were verified empirically (using correlation, regression and MCA correspondence (Tworek, 2019)) and its usefulness for the assessment of IS in the organization has been validated on several different research trials (Tworek, 2019, Bieńkowska et al., 2018). All the empirical studies carried out so far have confirmed its completeness and usefulness, which gives the basis for applying it to the IS assessment in the organization in the context of examining their relation with the level of employees' commitment in the organization.

\subsection{IS Reliability and the Level of Employees' Commitment}

Kompaso and Sridevi (2010), Clifton (2008) and Macey and Schneider (2008) define a set of strategies for shaping employees' commitment in the organization. Their in-depth analysis seems to be 
a sufficient basis to assume that the reliability of IS in an organization can actually have a significant relation with the level of employees' commitment while being an important element of the implementation of the indicated strategies. Among the many strategies discussed in the literature, as the most important in the context of the subject of this article the following ones should be mentioned:

Starting from the first day, important in the context of proper selection of employees and talent management. The emphasis is placed on the importance of the first day at work, aimed at introducing different strategies for shaping commitment from the very beginning of work in the organization (Kompaso and Sridevi, 2010). One of the important elements of the first day at work is gaining access to the IS, which the employee will use to accomplish his / hers tasks and assess their reliability already at this stage - hence, it becomes a factor that can shape the level of the commitment (Tworek, 2019).

Bilateral communication, stating that employees should not only listen and follow instructions of their superiors, but actively participate in solving problems, decision-making processes and making decisions about their obligations (Kompaso and Sridevi, 2010). It seems undisputed that the IS, which one of the main goals is to improve communication channels and information flow inside the organization (Crowston, 2000) and the level of their reliability are affecting their actual use (i.e., the employee's conviction that communication and information exchange is more effective with their use rather than without it). Hence, IS reliability definitely appears as a factor necessary to implement this strategy.

Providing resources to employees. It should enable employees to use all the resources of the organization needed to effectively carry out their tasks (Kompaso and Sridevi, 2010). Currently, one of the key resources in most organizations ,necessary to carry out the tasks, is a reliable IS (Bieńkowska et al., 2018), and employees should be convinced of their usefulness and use them to carry out their tasks voluntarily rather than with coercion from superiors. For such a situation to take place, they must be perceived as reliable (and also the information contained therein).

Continuous education, which is enabling employees to participate in trainings. The consent to their training to be a part of their working time is necessary to shape their commitment and support their willingness to improve their work and competence (Kompaso and Sridevi, 2010). IS enables remote access to content supporting trainings (e-learning, TEDy, etc.), potentially contributing to the more effective implementation of this strategy, assuming that employees perceive it as useful.

An effective employee as a model. Employees' attention should be focused around those individuals who are most effective in their work. Watson Wyatt Worldwide conducted empirical research in 2004 and 2005 and on their basis indicated that the organizations achieving the best results focus their activities around the employees who are the most effective and reliable IS enables effective spread of problem solutions developed by them within the organization (Kompaso and Sridevi, 2010).

On the basis of the literature analysis presented here, it therefore seems legitimate to formulate the following hypothesis:

\section{H1: The higher the level of SI reliability in the organization, the higher is the level of employees' commitment.}

\section{RESEARCH METHOdOLOGY}

The survey was conducted in order to verify the proposed hypotheses and identify the level of IS reliability and employees' commitment for every considered organization. The main survey was preceded by the pilot survey conducted in early 2018 among the group of 50 organizations in order to explain the issues concerning ambiguity of several questions. According to obtained results, the ambiguous questions were rewritten in order to obtain more informed response from the organizations participating in main survey. The main research was conducted as a part of a research project "The IT reliability influence on the quality of management methods and techniques", no. 2017/01/X/HS4/ 01967 financed from the funds of the National Science Center in Poland. The main survey was conducted in March 2018, among organizations located in Poland, which was the only condition limiting the sample (regardless of size, industry or type of business etc.), using online survey service: Survey Monkey. Only one survey was carried out anonymously in one organization, and it was 
completed by employees who have a broad view of the entire organization. Efforts had been made to make sure that the questionnaire was filled by organizations of all sizes and all types. In the main studies 557 full answers were collected, which is a very big test for this type of research (Tab 1). Out of this sample, 525 organizations declared implementation of mechanisms for building the level of employees' commitment and decided to assess both the level of IS reliability and the level of employees' commitment. The statistical analysis of the results aimed at verifying the formulated hypothesis was carried out using the SPSS Imago software and included: analysis of the coherence of the scales and correlation analysis.

Table1. Research sample characteristics

\begin{tabular}{|l|l|l|l|l|}
\hline \multicolumn{1}{|c|}{ Organization size } & \multicolumn{1}{|c|}{$\begin{array}{c}\text { Manufacturing } \\
\text { organizations }\end{array}$} & $\begin{array}{c}\text { Service } \\
\text { organizations }\end{array}$ & $\begin{array}{c}\text { Trade } \\
\text { organizations }\end{array}$ & Total \\
\hline Micro (below 10 people) & 66 & 31 & 10 & 106 \\
\hline Small (11-50 people) & 48 & 72 & 20 & 140 \\
\hline Medium (51-250 people) & 42 & 77 & 15 & 134 \\
\hline Large (above 250 people) & 71 & 92 & 14 & 177 \\
\hline Total & 227 & 272 & 59 & 557 \\
\hline
\end{tabular}

Source: (Bieńkowska, Tworek, Zabłocka-Kluczka 2018).

Empirical research made it possible to assess the level of IS reliability and the level of employee commitment in the organization.

The level of IS reliability was assessed on the Likert scale (from very poor - 1 to very good - 5) based on the methodology developed by Tworek (2019) and described in the first part of the article. This variable was built from the factors identified as part of the description of each of the four elements of the IS reliability model: reliability of the system (software and hardware), its usage, information contained therein and support services. Cronbach's alpha coefficient for this variable is high (0.947), which confirms the coherence of the proposed scale.

The level of employees' commitment was assessed on the Likert scale (from I strongly disagree - 1 to I strongly agree - 5) based on a set of statements formulated on the basis of the methodology proposed by Mone and London (2009).This variable was built from 8 factors corresponding to 8 elements identified in the proposed methodology, described in the first part of the article. Cronbach's alpha coefficient for this variable is high (0.911), which confirms the coherence of the proposed scale.

\section{RESEARCH RESULTS}

In order to verify the formulated hypothesis, a correlation analysis was conducted between the variable IS reliability and the variable level of employees' commitment. The results presented in Table 2 clearly indicate that there is a statistically significant (at $\mathrm{p}<0.05$ ), however, a weak correlation between the indicated variables in the tested sample. In addition, a statistically significant correlation occurs between all 4 elements that build the IS reliability in the organization and the level of employees' commitment, which further confirms the importance of all aspects of IS reliability for the analyzed relation.

Table2. Correlation of $r$-Pearson between the level of SI reliability and the level of employees' commitment

\begin{tabular}{|l|l|}
\hline \multicolumn{1}{|c|}{ Correlation } & \multicolumn{1}{c|}{ Level of emploees' commitment } \\
\hline IS reliability & $\mathrm{r}(525)=0,215, \mathrm{p}<0,05$ \\
\hline System reliability & $\mathrm{r}(525)=0,190, \mathrm{p}<0,05$ \\
\hline Usage reliability & $\mathrm{r}(525)=0,264, \mathrm{p}<0,05$ \\
\hline Information reliability & $\mathrm{r}(525)=0,228, \mathrm{p}<0,05$ \\
\hline Support service reliability & $\mathrm{r}(525)=0,226, \mathrm{p}<0,05$ \\
\hline
\end{tabular}

Source: own work

The conducted research indicated that the higher level of employees' commitment is usually accompanied by a higher level of IS reliability in the organization (higher level of system reliability (software and hardware), its usage, information contained therein and support services). Moreover, the slightest, although noticeably strongest relation exists between the level of reliability of system usage and the level of employees' commitment, which remains consistent with the analysis of literature (Fig. 2). 


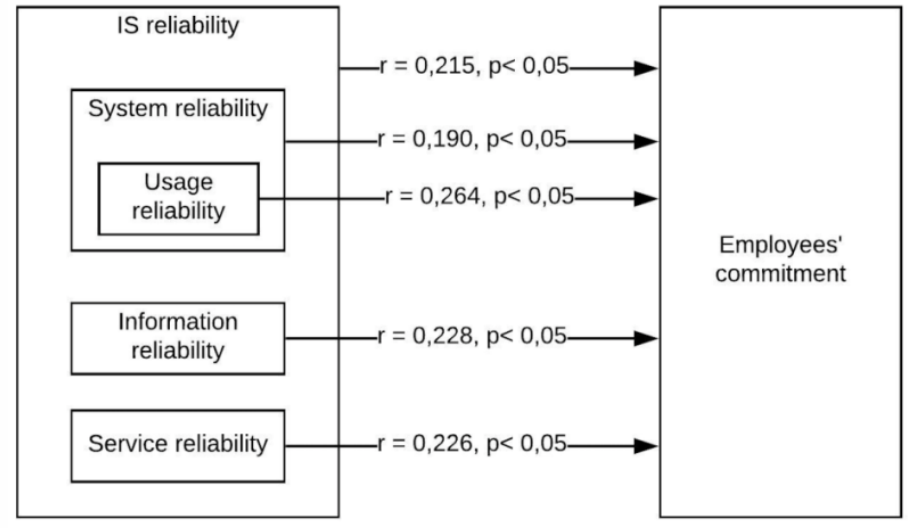

Fig2. Results of the analysis of the correlation between the level of IS reliability in the organization and the level of employees' commitment.

Source: own work

It should be noted that the role of IS in supporting the strategy of building employees' commitment is clearly related to the use of the IS. Elements that build reliability of usage (and above all the level of system acceptance, for which the correlation coefficient with the level of employees' commitment is the highest, $\mathrm{r}(525)=0.276, \mathrm{p}<0.05)$ are directly related to the perceived usability of the IS. This usefulness directly affects the willingness of the employee to use the IS to carry out tasks (Davis, 1987) and the more voluntary is that use, the greater its impact on the level of employees' commitment (Kompaso and Sridevi, 2010). Therefore, the hypothesis formulated on the basis of literature reports suggesting that the reliability of usage determines to the greatest the extent of the impact of reliability of IS used in the organization on the level of employees' commitment is confirmed. On the basis of the conducted analysis, it is necessary to positively verify the formulated H1 hypothesis and state that the higher the level of IS reliability in the organization (and in particular the reliability of the system usage, including its acceptance), the higher is the level of employees' commitment.

\section{CONCLUSiOnS}

The purpose of this article was to verify the relation between the level of employees' commitment and IS reliability in the organization (which identifies, among others, the IS usefulness perceived by employees) as the first step verification of IS reliability as a factor that can shape employees' commitment in the organization. The empirical studies conducted on a sample of 557 organizations operating in Poland showed that there is a weak but statistically significant relation between the level of IS reliability (including the reliability of the system (software and hardware), its usage, information contained therein and support services) and the level of employees' commitment. This was confirmed by literature reports (Kompaso and Sridevi, 2010, Clifton, 2008) indicating that IS used by employees in the organization can be considered as one of the factors potentially shaping the level of employees' commitment and this is worth to be the subject of further research. In addition, the research showed that the most important element that constitutes the reliability of IS in the organization from the point of view of dependence with the level of employees' commitment is the reliability of usage - this is also confirmed by literature describing it as the most influential element of the utility of the IS perceived by employees.

The conducted research being the basis for the verification of the hypothesis have their limitations. The research sample was limited to a group of 557 organizations (this is not a representative sample for all organizations operating in Poland). In addition, it was limited to one geographical location and thus to one business context (Poland) - which is also a strength of the results characterizing this particular business context. However, they seem sufficient to initially verify the relation between the level of IS reliability in the organization and the level of employees' commitment and to indicate further directions of research.

\section{ACKNOWLEDGEMENT}

The paper was created as a result of the research project no. 2017/01/X/HS4/01967 financed from the funds of the National Science Center. 


\section{REFERENCES}

[1] Bieńkowska A., Tworek K., Zabłocka-Kluczka A. (2018), Information technology reliability influence on controlling excellence, Raport PWr serii PRE no. 11/2018.

[2] Clifton, J. K. (2008), Engaging your employees: Six keys to understanding the new workplace. SHRM .

[3] Davis, F. D. (1985), A technology acceptance model for empirically testing new end-user information systems: Theory and results (Doctoral dissertation, MIT USA).

[4] Delone, W. H., McLean, E. R. (2003), The DeLone and McLean model of information systems success: a ten-year update. "Journal of management information systems", 19(4), pp. 9-30.

[5] Grobelna, A. (2014),Zarządzanie zaangażowaniem pracowników w kontekście wzrostu konkurencyjności przedsiębiorstw hotelowych na współczesnym rynku. „Logistyka”, (3), pp. 2202-2211.

[6] Jha, B., \& Kumar, A. (2016),Employee engagement: A strategic tool to enhance performance. DAWN: „Journal for Contemporary Research in Management”, 3(2), pp. 21-29.

[7] Juchnowicz, M. (2010),Zarządzanie kapitałem ludzkim a poziom zaangażowania pracowników,,, Zarządzanie Zasobami Ludzkimi”, (3-4), pp. 57-66.

[8] Kim, S., \& Lee, H. (2006), The impact of organizational context and information technology on employee knowledge-sharing capabilities, "Public administration review", 66(3), pp. 370-385.

[9] Kompaso, S. M., Sridevi, M. S. (2010),Employee engagement: The key to improving performance, "International journal of business and management", 5(12), p. 89.

[10] Little, R. G. (2003, January),Toward more robust infrastructure: observations on improving the resilience and reliability of critical systems. [In:] System Sciences, 2003. Proceedings of the 36th Annual Hawaii International Conference on (pp. 9-pp). IEEE.

[11] Lyytinen, K. (1987), Different perspectives on information systems: problems and solutions. ACM Computing Surveys (CSUR), 19(1), pp. 5-46.

[12] Macey W.H, Schneider B. (2008), The Meaning of Employee Engagement, "Industrial and Organizational Psychology", 1 (2008), pp. 3-30.

[13] Marrelli, A. F. (2011),Employee engagement and performance management in the federal sector, "Performance Improvement", 50(5), pp. 5-13.

[14] Mone, E. M., \& London, M. (Eds.). (2009). HR to the Rescue. Routledge.

[15] Mone, E. M., \& London, M. (2018), Employee engagement through effective performance management: A practical guide for managers. Routledge.

[16] Robinson D., Perryman S., and Hayday S. (2004), The Drivers of Employee Engagement Report 408, Institute for Employment Studies, UK

[17] Tworek, K. (2016), Model niezawodności systemów informacyjnych $w$ organizacji, „ZN Organizacja i Zarządzanie/Politechnika Śląska”, (88), pp. 335-342.

[18] Tworek, K. (2018), Information systems reliability in the context of higher education institutions. EDULEARN18, 10th annual International Conference on Education and New Learning Technologies: Conference Proceedings, Palma de Mallorca (Spain). 2nd - 4th of July, 2018. IATED Academy.

[19] Tworek, K. (2019), IT and Busines Alignment, Springer, Switzerland.

[20] Wood, S., \& De Menezes, L. (1998),High commitment management in the UK: Evidence from the workplace industrial relations survey, and employers' manpower and skills practices survey, "Human Relations", 51(4), pp. 485-515.

[21] Zahedi, F. (1987). Reliability of information systems based on the critical success factorsformulation. "Mis Quarterly", pp. 187-203.

Citation: Katarzyna Tworek. "Employees' Engagement in the Context of the Reliability of Information Systems in the Organization" International Journal of Managerial Studies and Research (IJMSR), vol 7, no. 2, 2019, pp. 12-18. doi: http://dx.doi.org/10.20431/2349-0349.0702003.

Copyright: (C) 2019 Authors. This is an open-access article distributed under the terms of the Creative Commons Attribution License, which permits unrestricted use, distribution, and reproduction in any medium, provided the original author and source are credited. 